\title{
WAYS FOR IMPROVING OF FISCAL-ACCOUNTING REGULATION TO THE CONTEXT OF AGRICULTURAL EXPORTS IN UKRAINE ACCORDING TO THE WORLDTRENDS
}

\author{
Vasyl Voitseshyn ${ }^{1}$, Oleg Shevchuk ${ }^{2}$ \\ ${ }^{1}$ Department of Taxes and Fiscal Policy, West Ukrainian National University, Ternopil, Ukraine \\ aactivatorwiki@gmail.com \\ ORCID: http://orcid.org/0000-0001-6114-3046 \\ ${ }^{2}$ Department of Accounting and Taxation, West Ukrainian National University, Ternopil, Ukraine \\ ikaf@ukr.net \\ ORCID: http://orcid.org/0000-0002-7352-7001
}

ARTICLE INFO

Article history:

Received date 20.01.2021

Accepted date 22.02.202

Published date 28.02.2021

Section:

Accounting

DO I

$10.21303 / 2313-8416.2021 .001672$

KEYWORDS

agricultural products

fiscal-accounting regulation

exports

export duty

revenues
A B S TRACT

The object of research: the procedural order of fiscal and accounting regulation of revenues from export agricultural products (export receipts, the export duty).

Investigated problem: obtaining stable and repetitive connection between the accounting part, the fiscal part of the regulation and exports of agricultural goods with possibility of improvement.

The main scientific results: it is revealed that the first stage of fiscal-accounting regulation of exported agricultural products is transactions' accounting on accounts. It should be noted that, after the abolition of the mandatory sale in Ukraine, there is no need to apply the distributive account in export of agricultural products. It will help to reduce the time of enrollment the currency and its using by exporters for their needs. It is determined too, that the second stage of the regulation is the export receipts and revenues from the export duty. Moreover, using economic (mathematical) modeling, based on correlation-regression analysis, it is illustrated positive effects for reducing of export duty rates on revenues from export agricultural products in Ukraine.

The area of practical use of the research results: Government of Ukraine in formation of export strategy, and exporters - in the context of accounting.

Innovative technological product: the regulation technology of the cyclical accounting and fiscal parts in agricultural exports with using modeling econometric analysis for determination of direction of its development.

Scope of the innovative technological product: Ukraine's Government practice in using mathematic modeling for determination of trends of agricultural exports.

(C) The Author(s) 2021. This is an open access article under the CC BY license http://creativecommons.org/licenses/by/4.0).

\section{Introduction}

\section{1. The object of research}

The object of research is the procedural order of fiscal and accounting regulation of revenues from export agricultural products (export receipts, the export duty).

\section{2. Problem description}

Due to dynamic market environment in the agricultural international trade the fiscal-accounting regulation becomes an important tool. The regulation covers almost the entire export process of the goods: from production to sale. Due to time repetition, the regulation is characterized by cyclicality. In addition, it is aimed at the long-term period. It helps to develop the agricultural exports in the country, and allows realize its potential.

Ukraine's onward integration with the World Trade Organization (WTO) and the Europe Union (EU) has necessitated improvement accounting and fiscal procedures. In the case of accounting, it is reflected in the comparison of Ukraine's accounting with international one, and in the introduction of its automation through using of software package and devices. In contrast, in the fiscal part of the regulation, it manifests in trade liberalization (especially in reduction of duty rates on agricultural exports).

Taking into account Ukraine's commitments before the WTO and the EU it is possible to evaluate its impact on exported agricultural products and possibility of the potential's realization. 
In order to achieve the purpose, the following tasks are set with using:

- horizontal and vertical analysis to display data changing in dynamics;

- mathematic modeling, based on correlation-regression analysis, to determinate the interrelation between the change of time, shifting of agricultural export value and budget revenues from the export;

- method absolute and relative values for calculating loses from non-realization of agricultural export potential for one method;

- absolute increase and the value of the $1 \%$ of increase to detect the change percentage of exported agricultural products and other revenues from the exports to another one.

It helps to sum up processes of the fiscal-accounting regulation in context of national agricultural exports.

There are many explorations that are related to the fiscal-accounting of agricultural exports. For example, the features of exported agricultural goods and its development in some regions according to resource provision, state policy and other uncontrolled factors have been researched by such Ukrainian and foreign scientists, as Yu. Bilyansky [1], S. Urba [2], A. Sulaiman, M. Ali, A. Ahmad [3], F. Joy [4]. It was paying attention on necessity for an appropriate climate for producing, good processing system, favorable state policy and ability to adapt for adverse conditions.

The possibility of using the agricultural exports in the context of a budget's source is revealed by N. Shmygol, A. Antoniuc \& D. Anikieieva [5] in the study [3]. It concentrated on fiscal role's increasing of export duty due to temporary growth of taxation objects (wheat, corn).

In addition, in our previous research [4] it is presented through models of information exchange for specially equipped agricultural machinery, GPS-navigation equipment (GPS-modules, maps) and precision farming system (agro-navigators with supporting of field maps).

\section{3. Suggested solution to the problem}

However in the investigations, thus far, the focus has not been on modeling these processes taking into account not only retrospective consequences of exported agricultural products, but perspective ones too. So there are many unresolved issues in this area.

The aim of research is correlation-regression analysis for the fiscal-accounting regulation of Ukraine's agricultural exports for discovery of its state and ways to improve.

\section{Materials and Method}

According to our tasks, firstly let's evaluate the actual and the maximum exports of agricultural products in Ukraine and in the world through using Holt's forecast method of modeling in MS EXCEL. In that case, the maximum exports $\left(A E_{2}\right)$ is based on the actual one $\left(A E_{1}\right)$ on year $(t)$ in previous period $(t-1)$, and the forecast export reminder $\left(f_{t}\right)$ :

$$
A E_{2}=A E_{2}(t-1)+f(t) \text {. }
$$

For showing the tendency of agricultural export development, let's build correlation-regression models that could show dependence between $t(X)$ and $A E_{1}(Y)$ :

$$
Y=X^{k}+X^{k-1}+\ldots+t, k=1, n
$$

After the illustration let's show the accounting part of fiscal-accounting regulation for agricultural export products in Ukraine and in the world. Let's analyze main differences between national accounting and international one.

Based on the research, it is also possible to illustrate the direct connection between the accounting and the fiscal part of the regulation.

Then let's evaluate loss from non-realization of the maximum exports in Ukraine by using following three methods:

1. Absolute and relative values, where:

- let's calculate the cost of the agricultural products, that are subject to the export duty $\left(A E_{U A 1}^{D}\right)$. In the case, let's sum up the value of every agricultural export goods (sunflower, red, sheep etc.); 
- based on fraction $A E_{U A 1}^{D}$ in export goods, let's evaluate the value of export duty for agricultural products $\left(E D_{A 1}\right)$;

- then let's calculate the part $E D_{A}$ in $A E_{U A 1}^{D}$ and, after that, the result multiple by the maximum agricultural exports $\left(A E_{U A 1}\right)$. Let's receive the export duty value in the case of $A E_{U A 1}\left(E D_{A 2}\right)$;

- for finding the loss, let's subtract $E D_{A 2}$ from $E D_{A 1}$.

2. Method of substitution:

- firstly, let's find the regression connection (2) between the $A E^{D}{ }_{U A 1}\left(X^{*}\right)$ and value of export duty from agricultural goods $\left(E D_{A 1}-Y^{*}\right)$;

- secondly, it is necessary to calculate the index that shows the ratio between $A E_{2}$ and $A E_{1}-I_{A E}$;

- when evaluate $\mathrm{I}_{\mathrm{AE}}$, it is possible to calculate the maximum value of agricultural exports, that is subject to export duty $\left(A E_{U A 2}^{D}\right)$ by multiply $\mathrm{I}_{\mathrm{AE}}$ to $A E_{U A 1}^{D}$;

- finally, let's substitute $X$ from $A E_{U A 1}^{D}$ to $A E_{U A 2}^{D}$ in the regression and find $E D_{A 2}$;

- for finding the loss, let's subtract $E D_{A 2}$ from $E D_{A 1}$.

3. Combination of the arc elasticity and absolute value of the $1 \%$ of increase methods:

- It is necessaryto find the absolute value of the $1 \%$ of increase for $E D_{A 1}(A V 1)$ and $A E_{U A 1}^{D}$ $(A V 2)$ by using (3):

$$
Y(X)_{t=} Y(X)_{t-1} / 100
$$

- for finding the loss, let's subtract $E D_{A 2}$ from $E D_{A 1}$.

After calculations, let's use the foreign trends in the regulation and evaluate the ways for improving the fiscal-accounting regulation of agricultural exports in Ukraine.

\section{Result}

Based on our tasks, foremost let's evaluate the relationship between time change and the actual (statistical) value of agricultural export in Ukraine $\left(A E_{U A 1}\right)$, and in the world $\left(A E_{W 1}\right)$, based on Table 1.

Table 1

Actual and maximum exports in Ukraine and in the world

\begin{tabular}{ccccc}
\hline \multirow{2}{*}{ Year } & \multicolumn{4}{c}{ Indicators, million USD } \\
\cline { 2 - 5 } & $\boldsymbol{A \boldsymbol { E } _ { U A 1 }}$ & $\boldsymbol{A \boldsymbol { E } _ { U A 2 ^ { * } }}$ & $\boldsymbol{A \boldsymbol { E } _ { W 1 }}$ & $\boldsymbol{A} \boldsymbol{E}_{\boldsymbol{W} 2}$ \\
\hline 2009 & 7431.30 & 7431.30 & 175724.22 & 175724.22 \\
2010 & 7368.22 & 8765.37 & 236307.97 & 236307.97 \\
2011 & 9869.21 & 9869.21 & 299446.79 & 299446.79 \\
2012 & 14394.33 & 14394.33 & 279206.59 & 279206.59 \\
2013 & 13478.48 & 13478.48 & 280713.71 & 280713.71 \\
2014 & 13597.46 & 13597.46 & 271440.24 & 271440.24 \\
2015 & 12107.65 & 13292.66 & 235322.77 & 236093.47 \\
2016 & 12845.97 & 13522.65 & 231019.14 & 250886.06 \\
2017 & 12119.94 & 13757.91 & 255656.40 & 265307.23 \\
2018 & 12596.25 & 14201.27 & 273731.41 & 291005.95 \\
2019 & 15717.97 & 15717.97 & 254599.14 & 308038.89 \\
SUM & 131526.78 & 138028.62 & 2793168.38 & 2894171.12
\end{tabular}

Note: *_ "2" means 'the maximum exports', which based on actual one with calculated forecast value, and is the actual exports stable crisis-free economic growth; it is computed by using data [5, 6] and Holt's forecast mathematic modeling [7]; the maximum export can't be less than the statistical one

According to the Table 1 even in spite of crisis, the agricultural exports have grown as in Ukraine, as in the world. There is an incomplete realization in Ukraine's agricultural exports both in general and by periods (2009, 2015-2018). The similar situation applies to the world exports. Moreover, increasing in the share of that Ukrainian exports in the world one amounted to $11.35 \%$ from 2009 to 2019. 
Inasmuch data, let's build the correlation-regression models. They have represented the dependence between the change of time $(X), A E_{U A 1}\left(Y_{1}\right)$ and $A E_{W 1}\left(Y_{2}\right)$ accordingly with $95.00 \%$ level of reliability (or $5.00 \%$ error), such as in the research [8].

For confirming the models let's have used some indicators. as in [8]:

- the coefficient of correlation for closeness (r), coefficient of determination for dependence of change between $Y$ and $X\left(R^{2}\right)$;

- Fisher's Criterion $(F-t)$ and Student's T-Test $(T-t)$, that exceeding their tabular values, - for checking models' quality;

- the absolute error $\left(A_{E}\right)$ and/or the relative one $\left(R_{E}\right)(<10.00 \%)$ - for confirming the adequacy of $r, R^{2}$ and models:

$$
\begin{gathered}
\mathrm{Y}_{1}=7.34 X^{4}-59.153 X^{3}+178589653.46 X^{2}-239634416872.12 X^{1}+120579231807016.00 ; \\
r=99.81 \% ; R^{2}=97.65 \% ; F-t=454.12>5.12 ; \\
T-t=19.34>2.26 ; A_{E}=2.86 \% ; R_{E}=0 .
\end{gathered}
$$

According to qualitative (4), the change of $A E_{U A 1}$ was characterized by fluctuations (polynomial model with one expressed peak and bottom as a result of crisis after 2014).

The trend in the change of $A E_{W 1}$ is similar with the deference in the constant alternation of ups and downs.

$$
\begin{gathered}
Y_{1}=837.21 X^{3}-5060170.61 X^{2}+ \\
+10194664179.56 X^{1}-6846346353003.21 ; \\
r=95.64 \% ; R^{2}=91.47 \% ; \\
F-t=9.82>5.12 ; \\
T-t=9.82>2.26 ; \\
A_{E}=2.89 \% ; \\
R_{E}=0.13 \% .
\end{gathered}
$$

From the vector of the accounting $A E_{U A 1}$ is foreign exchange revenue. In Ukraine and in the world the revenue is recognized as the asset and is accounted to on the distribution account 316 "Special accounts in foreign currency" for mandatory currency's sale [9, 10]. But, after the abolition of the mandatory sale of revenue by exporters in 2019 [10], they could sale or not sale their revenues. In the first case, accounting will look like: debit 311 "Current accounts in national currency" - credit 316 "Special accounts in foreign currency". Moreover, in the second one, accounting could look the following way: debit 312 "Current accounts in foreign currency" - credit 316 "Special accounts in foreign currency".

It should be noted, that the income after shipment of products is recorded in account 701 "Income from sales of finished products" [10] according to national accounting standards. In opposite, according to international accounting standards, such income will be recorded on accounts 611 with the same name and 263 "Currency account" abroad [11]. So, it is worth noting, that there are no distribution accounts in the world practice.

In our opinion, after the abolition of the mandatory sale, there is no need to apply the account 316 in export of agricultural products. It is possible to use, as in the world, directly account 311 or 312 one, that depend of selling/not selling the export revenue. It will help to reduce the time of enrollment the currency and its using by exporters for their needs.

For increasing revenues from agricultural exports and to accounting improvement it is necessary to use unmanned aerial vehicles for collecting primary accounting information (crop area, harvest). The information could be transmitted to the clouded Internet-environment and used to 
generate electronic reports in a consolidated tabular/graphical form. It helps in analyzing of production's state.

The connection between the fiscal regulation and the accounting one could be traced in the implementation of some business transactions. They are related to payment of export duty and value-added tax (VAT). For example, in Ukraine accounting entries for VAT's obligation will take such form: debit 701 - credit 641 (in the case, when the tax rate is $0 \%$ ). As for export duty in Ukraine, in addition to its reflection in revenue for accounting, it is a conduct that shows funds' transfer to customs authorities for payment of custom duties: debit 377 "Settlements with other debtors" - Credit 311 "Current accounts in national currency". It means that in theory exporters need to sell some currency for paying the export duty.

According to international accounting standards, accounting entries for export takes will look like: debit 611 "Income from sales of finished products" - credit 533 "Tax calculation"; debit 243 "Payments to the budget" - credit 262 "Current account" (money's transfer from account 263).

In obedience to researches, it is possible to evaluate the effect of the export duty functioning on agriculture exports in Ukraine.

Based on the first method, by using data $[5 ; 12]$ :

- the cost of agricultural products, that are subject to the export duty $\left(A E_{U A 1}^{D}\right)$ in million USD: 208.58 (2009); 194.13 (2010); 669.15 (2011); 189.32 (2012); 58.16 (2013); 66.13 (2014); 49.70 (2015); 113.24 (2016); 80.94 (2017); 75.38 (2018); 96.51 (2019);

- the value of export duty for agricultural products in million USD $\left(E D_{A 1}\right): 45.36$ (2009); 36.45 (2010); 150.11 (2011); 18.99 (2012); 4.80 (2013); 7.54 (2014); 25.40 (2015); 9.33 (2016); 7.28 (2017); 6.16 (2018); 5.42 (2019);

- the part $E D_{A}$ in $A E_{U A 1}^{D}, \%: 0.61$ (2009); 0.50 (2010); 1.52 (2011); 0.13 (2012); 0.04 (2013); 0.06 (2014); 0.05 (2015); 0.07 (2016); 0.06 (2017); 0.05 (2018); 0.03 (2019). After that we have received the export duty value in the case of $A E_{U A 1} 3$, million USD: 45.36 (2009); 43.36 (2010); 150.11 (2011); 18.99 (2012); 4.80 (2013); 7.54 (2014); 5.92 (2015); 9.82 (2016); 8.27 (2017); 6.94 (2018); 5.42 (2019);

- the loss of export duty in Ukraine from non-realization of export level, million USD: 0 (2009, 2011-2014, 2019); 6.91 (2010); 0.53 (2015); 0.49 (2016); 2017 - 0.98 (2017); 0.78 (2018). Overall, from 2009 to 2019, the loss was 9.70 million USD or $3.32 \%$ (with incomplete agricultural exports of $4.70 \%$ ).

For finding loses from non-realization of the agricultural export in Ukraine let's fuse the regression connection between the $A E_{U A 1}^{D}\left(X^{*}\right)$ and value of export duty from agricultural goods $\left(E D-Y^{*}\right)$ :

$$
\begin{aligned}
& Y^{*}=0.24 X^{* 1}-12.41 ; r=98.95 \% ; R^{2}=97.93 \% ; \\
& F-t=519.65>5.12 ; T-t=20.63>2.26 ; R_{E}=0 \% .
\end{aligned}
$$

After determination of the dependence, based on Table 1, it is necessary to calculate the index that shows the ratio between $A E_{U A 2}$ and $A E_{U A 1}-I_{A E}$. For example, for 2010 it value was 1.19.

When $\mathrm{I}_{\mathrm{AE}}$ is evaluated it is possible to calculate the maximum value of agricultural exports that is subject to export duty $\left(A E_{U A 2}^{D}\right)$ by multiply $\mathrm{I}_{\mathrm{AE}}$ to $A E_{U A 1}^{D}$. For example, in $2010 A E_{U A 2}^{D}$ was 231.02 million USD.

After that let's insert $A E_{U A 2}^{D}$ in (6). In addition, let's receive the export duty in case of maximum exports, and losses from non-realization agricultural exports. So, according to our research, from 2009 to 2019 lost revenues from the export duty is by near 16.44 million USD or $5.54 \%$ (for example, in 201214.15 million USD were lost).

For showing the loss of the export duty let's also use combination of the arc elasticity and absolute value of the $1 \%$ of increase methods.

First of all, let's find $A V 1$ for the duty by using (3). There are such results in million USD: 0.454 (2010); 0.364 (2011); 1.501 (2012); 0.190 (2013); 0.048 (2014); 0.075 (2015); 0.054 (2016); 0.093 (2017); 0.073 (2018); 0.062 (2019).

In the similar way let's find $A V 2$ for the $A E_{U A 1}^{D}$ in million USD: 2.086 (2010); 1.941 (2011); 6.692 (2012); 1.893 (2013); 0.582 (2014); 0.661 (2015); 0.497 (2016); 1.132 (2017); 0.809 (2018); 0.754 (2019). 
Then let's evaluate $E D_{A 2}$ for 2010, in million USD, by using (4), considering that $E D_{A 2}(2009)=E D_{A 1}(2009)$ in all previous cases:

$$
E D_{A 2}=45.36+((0.454 * 10.72) / 2.086)=47.70
$$

There are such results for all discovering periods in million USD: 77.64 (2011); 61.55 (2012); 54.61 (2013); 55.74 (2014); 53.74 (2015); 65.46 (2016); 63.66 (2017); 63.07 (2018); 64.05 (2019). The general loss was 291.69 million USD or $98.27 \%$.

Based on research it is possible to say that for Ukraine the loss from non-realization of agricultural exports is from 3.32 to $98.27 \%$. It depends on different evaluation methods and means that it is necessary to find some solutions for deciding the problem.

Considering our previous research [10] it is possible to say that one of the fiscal way for short-time period to solve the problem is gradual decrease of the export duty. It is a requirement of the EU from 2016 for our country, which adhered to by many developed countries. It could spread not only for the EU-countries, but for other ones too. From mathematic view it is effective because of reducing the burden on exporter.

For calculating value of the export duty, that could be existence in the case of action of the duty rates according to the EU for all agriculture merchandise let's use (8) from research [10]:

$$
E D_{A U}^{*}(t)=E D(t-1)+(((A D r(t)-A D r(t-1)) * C E) * A V t),
$$

where $E D(t-1)$ - export duty in base period; $A D r$ - export duty rate, $C E$ - arc elasticity coefficient; $A V t$ - the absolute value of the $1 \%$ of increase for the export duty.

According to the calculation, the reducing of the export duty could be increase the duty in 2017 by near $27.00 \%$ :

$$
E D_{A U}^{*}(2017)=9.33+(((9.75-8.62) * 2.01) * 1.132)=11.90 \text { million USD. }
$$

By analogy, in 2018 that indicator was $15.00 \%$, and, in $2019-14.00 \%$.

So, the modeling shows the ways for improvement the fiscal-accounting regulation of exported agricultural products in the case of increasing in budget revenues.

\section{Discussion}

Exploring the impact of the fiscal-accounting regulation on the agricultural exports in Ukraine only Holt's forecasts mathematic modeling in MS EXCEL with traditional vertical and horizontal analysis was used. But, it is possible to combine the methods with the arc elasticity coefficient, which was only used in economics for determining the dependence between the product's price and quantity of products. Moreover, let's use the absolute value of the $1 \%$ of increase for showing the value of benefits in trade liberalization for Ukraine. Also, let's tie the accounting regulation of agricultural exports and the fiscal one, and showed the process of its regulation.

The content of our study is slightly different from other researches. For example, for calculating the maximal export of agricultural products let's use the polynomial one-factor modeling, where the export is dependent on time. In contrast, the study [13] shows the linear three-factors dependence between changing in exports, changing in imports, the inflation and capital investments. Based on data, in the research it is possible to observe the forecast in exports changing.

According to the study [14] the export value was appreciated by using only vertical and horizontal analysis in geographic and merchandise structure in dynamic. In addition, it was used some indexes, that shows general trends in exports (the export quota etc.).

The wide application of the graphical analysis for exports of individual goods and in general is presented in the study [15]. It clearly reflects trends in exports.

The complex using of methods (the expert method, the factor analysis, the correlation-regression analysis for assessment) was used in the research [16]. It lets show versatility of exports study not only from mathematic side, but from descriptive one too. 
Study limitations. When studying the agricultural exports let's use the data of Ukraine and in the World in general. Also, let's only took into account the period between 2008 and 2019, - from Ukraine's accession to the WTO to last available information.

When we calculated benefits from trade liberalization in Ukraine, let's only used MS EXCEL and one-factor models.

The prospects for the further research. To evaluate further consequences of the fiscal-accounting regulation on agricultural exports, it is necessary to use not only MS EXCEL, but other program complex (Statistica, as an example). Moreover, it is expedient to use, but several forecasting methods with new actual data. It helps to improve accuracy of calculation.

\section{Conclusions}

Among modern processes of the agriculture trade the fiscal-accounting regulation is actively applied. It is concerns to all economies of the world in response to modern requirements. In particular, it applies to Ukraine.

The fiscal-accounting regulation of agricultural export is a big system that operates funds from the export as the process.

The accounting part of the system reflects all export operations in paper and electronic documents from start to finish. Moreover, using the modern technologies helps to improve monitoring of agricultural producing.

The fiscal part of the regulation consists of export receipts and revenues to the budget from taxes, especially in the form of the export duty.

The analysis shows some problems in the fiscal-accounting regulation of agricultural exports in Ukraine. They apply to use of unnecessary accounts and loss of revenues from the export duty. Therefore, the country needs to focus on using the modern technology, especially in producing. It helps not only improve the monitoring quality, but also the process could reduce the formation time reporting.

Based on research it is possible to affirm about the opportunity of applying the world experience that based on the trade liberalization in the context of export duty rate reducing. It is expedient due to reduction of burden for exporters. Besides, it is possible to discontinue use the distribution account for export receipts if it not necessary for its selling at the banking market.

\section{References}

[1] Bilyansky, Yu. (2020). Efficiency of Institutional Security of Integration Processes in Foreign Economic Activity of Agricultural Enterprises of Ukraine. Innovative Economy, 1-2 (82), 105-116. doi: http://doi.org/10.37332/2309-1533.2020.1-2.16

[2] Felice, J. (2021). Glancing India's Agricultural Export Contribution During the Pandemic Period. International Journal of Modern Agricultural, 2, 53-62. Available at: http://www.modern-journals.com/index.php/ijma/article/view/437/359

[3] Shmygol, N. M., Antonyuk, A. A., Anikyeyeva, D. O. (2013). Export Tax in Ukraine. Motivations and Consequences. State and Regions, 4 (73), 16-21.

[4] Shevchuk, O., Desyatnyuk, O., Voitseshyn, V., Bryk, M., Muravskyi, V. (2020). Control and Accounting of the Transportation Services Self-cost using GPS. $202010^{\text {th }}$ International Conference on Advanced Computer Information Technologies, 631-634. doi: http://doi.org/10.1109/acit49673.2020.9208973

[5] State Statistics Service of Ukraine. Available at: http://www.ukrstat.gov.ua/

[6] Merchandise trade matrix - exports of individual economies in thousands United States dollars, annual. Available at: https:// unctadstat.unctad.org/wds/TableViewer/tableView.aspx?ReportId=195183

[7] Singh, A. P., Gaur, M. K., Agrawal, S., Kasdekar, D. K. (2015). Time Series Model Forecasting of Boot Using Holt, Winter and Decomposition Method. Journal of Industrial Safety Engineering, 2 (2), 23-31. Available at: https://www.researchgate.net/ publication/327847645_Time_Series_Model_Forecasting_of_Boot_Using_HoltWinter_and_Decomposition_Method

[8] Voitseshyn, V., Desyatnyuk, O., Shevchuk, O. (2020). Expediency of Reducing and Cancellation of Customs Duty's Level on Exports in Ukraine and in the World", $202010^{\text {th }}$ International Conference on Advanced Computer Information Technologies, 687-690. doi: http://doi.org/10.1109/acit49673.2020.9208981

[9] Pro zatverdzhennia Polozhennia pro zakhody zakhystu ta vyznachennia poriadku zdiisnennia okremykh operatsii v inozemnii valiuti (2019). Postanova Pravlinnia Natsionalnoho banku Ukrainy No. 5. 02.01.2019. Available at: https://zakon.rada.gov.ua/ laws/show/v0005500-19?lang=en\#Text

[10] Accountant 911. Available at: https://buhgalter911.com/uk/ 
[11] Chart of Accounts IFRS: Differences from National Standards and an Example of Compilation (2018). Available at: http:// vobu.ua/ukr/analytics/consultations/item/plan-schetov-msfo-otlichiya-ot-natsional-nykh-standartov-i-primer-sostavleniya-2

[12] State Treasury of Ukraine. Available at: https://www.treasury.gov.ua/ua

[13] Sozanskyy, I. (2016). The Prognosis of the Dynamics of Commodity Exports and Imports in Ukraine. Socio-Economic Problems of the Modern Period of Ukraine, 3 (119), 114-119.

[14] Senyshyn, O. S. (2014). Prognostic Growth Evaluation of Export Potential of Ukraine Food Complex. Scientific Bulletin of Kherson State University, 5 (1), 259-263,

[15] Zybrytskyy, A. I. (2015). Ukraine's Export Potential in the Context of Comparative Adventages. Economics and Forecasting, $1,140-154$.

[16] Chernobaj, L. I., Vatsyk, N. O., Kizlo, M. V. (2016). Statistical Methods Application in Cost Planning of Export Operations. Actual Problems of Economics, 11 (185), 408-424. 